\title{
Role for Reelin in Neurotransmitter Release
}

\author{
Sabine Hellwig, ${ }^{1,2}$ Iris Hack, ${ }^{1}$ Janina Kowalski, ${ }^{1}$ Bianka Brunne, ${ }^{1}$ Joel Jarowyj, ${ }^{1}$ Andreas Unger, ${ }^{1}$ Hans H. Bock, ${ }^{3}$ \\ Dirk Junghans, ${ }^{1 *}$ and Michael Frotscher ${ }^{1,3 *}$ \\ ${ }^{1}$ Institut für Anatomie und Zellbiologie, Albert-Ludwigs-Universität Freiburg, ${ }^{2}$ Neurologische Universitätsklinik, Neurozentrum, and ${ }^{3}$ Zentrum für \\ Neurowissenschaften, Albert-Ludwigs-Universität Freiburg, D-79104 Freiburg, Germany
}

The extracellular matrix molecule Reelin is known to control neuronal migration during development. Recent evidence suggests that it also plays a role in the maturation of postsynaptic dendrites and spines as well as in synaptic plasticity. Here, we aimed to address the question whether Reelin plays a role in presynaptic structural organization and function. Quantitative electron microscopic analysis of the number of presynaptic boutons in the stratum radiatum of hippocampal region CA1 did not reveal differences between wild-type animals and Reelin-deficient reeler mutant mice. However, additional detailed analysis showed that the number of presynaptic vesicles was significantly increased in CA1 synapses of reeler mutants. To test the hypothesis that vesicle fusion is altered in reeler, we studied proteins known to control transmitter release. SNAP25, a protein of the soluble $\mathrm{N}$-ethylmaleimide-sensitive factor attachment protein receptor (SNARE) complex, was found to be significantly reduced in reeler mutants, whereas other SNARE complex proteins remained unaltered. Addition of recombinant Reelin to organotypic slice cultures of reeler hippocampi substantially rescued not only SNAP25 protein expression levels but also the number of vesicles per bouton area indicating a role for Reelin in presynaptic functions. Next, we analyzed paired-pulse facilitation, a presynaptic mechanism associated with transmitter release, and observed a significant decrease at CA1 synapses of reeler mutants when compared with wild-type animals. Together, these novel findings suggest a role for Reelin in modulating presynaptic release mechanisms.

\section{Introduction}

During cortical development, the extracellular matrix protein Reelin, synthesized and secreted by Cajal-Retzius (CR) cells in the marginal zone of the cortex, is essential for the proper formation of cortical layers and the correct orientation of radially migrating neurons (D’Arcangelo et al., 1995, 1997; Rakic and Caviness, 1995; Curran and D'Arcangelo, 1998; Frotscher, 1998; Rice and Curran, 2001; Tissir and Goffinet, 2003; Soriano and Del Río, 2005; Förster et al., 2006a,b, 2010; Cooper, 2008; Chai et al., 2009; Zhao and Frotscher, 2010). The reeler mouse mutant deficient in Reelin exhibits inverted cortical layering and misoriented apical dendrites of pyramidal neurons. Reelin signaling involves the two lipoprotein receptors very-low-density lipoprotein receptor (VLDLR) and apolipoprotein E receptor 2 (ApoER2), and the adapter protein Disabled 1 (Dab1), which is phosphorylated by nonreceptor tyrosine kinases on binding of Reelin to its receptors (Howell et al., 1997; Sheldon et al., 1997; Ware et al., 1997; Lambert de Rouvroit and Goffinet, 1998; Hiesberger et al.,

Received July 30, 2010; revised Nov. 30, 2010; accepted Dec. 6, 2010.

This work was supported by Deutsche Forschungsgemeinschaft Grants Ha 4320/1-1, B0 1806/2-1, SFB 592, and SFB 780. Michael Frotscher was supported by The Hertie Foundation. We thank Dr. Imre Vida for his help with the physiological studies, Drs. K. Nakajima and T. Mikoshiba for the gift of the CR-50 antibody, and Sigrun Nestel, Barbara Joch, and Jutta Peschke for excellent technical assistance.

*D.J. and M.F. contributed equally to this work.

Correspondence should be addressed to Michael Frotscher, Institut für Anatomie und Zellbiologie, AlbertLudwigs-Universität Freiburg, Albertstrasse 17, D-79104 Freiburg, Germany. E-mail: michael.frotscher@ anat.uni-freiburg.de.

DOI:10.1523/JNEUROSCI.3984-10.2011

Copyright $\odot 2011$ the authors $\quad 0270-6474 / 11 / 312352-09 \$ 15.00 / 0$
1999; Trommsdorff et al., 1999; Arnaud et al., 2003; Bock and Herz, 2003). VLDLR and ApoER2 are thought to act in a similar fashion since both receptors are able to activate the Reelin signaling cascade. However, recent studies pointed to divergent functions of ApoER2 and VLDLR in the migration of cortical neurons during brain development (Hack et al., 2007).

Reelin is not only involved in early developmental processes such as neuronal migration and layer formation. There is ongoing Reelin expression after birth by numerous interneurons (Drakew et al., 1998; Pesold et al., 1998; Ramos-Moreno et al., 2006), and Reelin signaling was found to be involved in late steps of neuronal development such as dendritic differentiation and spine formation (Niu et al., 2004, 2008). In adult animals, Reelin modulates synaptic plasticity and memory by differential splicing of postsynaptic ApoER2 (Beffert et al., 2005) and by modulating NMDA receptor activity (Chen et al., 2005). Previous studies also indicated Reelin effects on the branching pattern and the number of synaptic contacts formed by axons of entorhino-hippocampal projection neurons (Del Río et al., 1997; Borrell et al., 1999). No effects of Reelin on presynaptic functions in adult animals have been reported so far.

In the present study, we provide evidence for presynaptic effects of Reelin. In reeler mutants, the number of synaptic vesicles of presynaptic boutons in CA1 stratum radiatum is increased when compared with wild-type animals, accompanied by decreased levels of SNAP25, a protein of the soluble $\mathrm{N}$-ethylmaleimide-sensitive factor attachment protein receptor (SNARE) complex (Parpura and Mohideen, 2008). Together with decreased paired-pulse facilitation (PPF), a presynaptic form of syn- 
aptic plasticity, these findings point to a role of Reelin in transmitter release at central synapses.

\section{Materials and Methods}

Animals

Experiments were performed in agreement with the German law on the use of laboratory animals and institutional guidelines of the University of Freiburg. Reeler mice were maintained on a B6/C3Fe background. ApoER2, VLDLR single- and double-mutant mice and Dab1 mutants were maintained on a mixed Sv129Ev $\times$ C57BL/6J background. The day of birth was considered postnatal day $0(\mathrm{P} 0)$.

\section{Immunohistochemistry}

Adult wild-type mice and reeler mutants ( $n=4$ for each genotype) were deeply anesthetized with sodium pentobarbital (Narcoren; Merial; 300 $\mathrm{mg} / \mathrm{kg}$ body weight) and fixed by transcardial perfusion as described previously (Deller et al., 2000). Brains were sliced coronally on a vibratome $(50 \mu \mathrm{m})$. Free-floating sections were blocked with a mixture of $10 \%$ horse serum (HS) and $0.5 \%$ Triton X-100 in PBS for $1 \mathrm{~h}$ at room temperature (RT) and incubated with mouse-anti-neuronal nuclei (NeuN) (mAB377; 1:1000 in PBS plus 10\% HS; Millipore), followed by secondary fluorochrome-conjugated antibodies (Alexa Fluor series; Invitrogen) in PBS for 2-3 h. Each step was followed by washing with PBS (three times for $10 \mathrm{~min}$ at RT). Sections were mounted on Superfrost glass slides in fluorescent mounting medium (Dako) containing $1 \mu \mathrm{g} / \mathrm{ml}$ 4',6-diamidino-2-phenylindole dihydrochloride (DAPI).

\section{Immunoblotting}

Mice (2-10 months of age) were anesthetized with $\mathrm{CO}_{2}$ and killed by cervical dislocation. Cortical and hippocampal tissues of wild-type and mutant animals were homogenized in ice-cold lysis buffer $(20 \mathrm{~mm}$ Tris$\mathrm{HCl}, 0.15 \mathrm{M} \mathrm{NaCl}, 2 \mathrm{~mm}$ EDTA, pH 7.5, protease inhibitor mixture; Roche Diagnostics). Lysates were cleared by centrifugation at $10,000 \times g$ two times for $5 \mathrm{~min}$ at $4^{\circ} \mathrm{C}$. The cytosolic fraction was removed by ultracentrifugation $\left(200,000 \times \mathrm{g}, 30 \mathrm{~min}, 4^{\circ} \mathrm{C}\right)$. After resolving the pellets in lysis buffer containing additional $0.1 \%$ SDS and $1 \%$ Triton X-100, the soluble membrane fraction was obtained by a second ultracentrifugation step $\left(100,000 \times g, 30 \mathrm{~min}, 4^{\circ} \mathrm{C}\right)$.

Sample preparation for protein analysis of hippocampal slice cultures was performed as follows: Tissue pellets $\left(-80^{\circ} \mathrm{C}\right)$ were lysed in ice-cold lysis buffer, pH 7.6 [50 mм Tris- $\mathrm{HCl}, 150 \mathrm{~mm} \mathrm{NaCl}, 5 \mathrm{~mm}$ EDTA, 1\% $(\mathrm{v} / \mathrm{v})$, Nonidet P-40, 0.5\% (w/v) SDS, $0.25 \%(\mathrm{w} / \mathrm{v})$ sodium deoxycholate], with $1 \%$ protease inhibitor (Sigma-Aldrich), and phosphatase inhibitor mixtures (Sigma-Aldrich) for $30 \mathrm{~min}$, triturated with a pipette, and centrifuged two times $\left(10,000 \times \mathrm{g}, 10 \mathrm{~min}, 4^{\circ} \mathrm{C}\right)$.

All samples were analyzed by standard SDS-PAGE and Western immunoblotting using chemiluminescence detection techniques (Super Signal West Pico; Perbio Science).

For semiquantitative analysis, five Western blots from five wild-type animals and mutant mice, respectively, were analyzed for each antibody. Films were digitally scanned and densitometry conducted using ImageJ 1.40 analysis software (National Institutes of Health). To control for inconsistencies in loading, protein bands of interest were normalized to actin loading controls.

For immunoblotting, the following primary antibodies were used: mouse anti-SNAP25 (1:1000; 111001; Synaptic Systems); mouse antisynaptobrevin-2 (1:1000; 104211; Synaptic Systems); rabbit anti-syntaxin1 (1:500; AB5820; Millipore); mouse anti-Munc18 (1:500; 116002; Synaptic Systems); mouse anti-synaptophysin (1:1000; 611880; BD Biosciences); mouse anti-synapsin 1 (1:2000; 106001; Synaptic Systems); mouse anticlathrin light chain $(1: 1000 ; 113011$; Synaptic Systems); and rabbit anti $\beta$-actin (1:5000; A2066; Sigma-Aldrich). Secondary antibodies were as follows: horseradish peroxidase (HRP)-linked sheep anti-mouse (1:10,000; NA931V; GE Healthcare) and HRP-linked donkey anti-rabbit (1:10,000; NA934V; GE Healthcare).

\section{Preparation of Reelin-containing supernatants and} control supernatants

Stably transfected HEK 293-cells expressing either full-length Reelin cDNA or green fluorescent protein (GFP) (D'Arcangelo et al., 1997;
Förster et al., 2002) were grown in DMEM, low glucose (Invitrogen), containing $10 \%$ fetal calf serum (Invitrogen), $1 \%$ penicillin-streptomycin (Invitrogen), and $0.9 \mathrm{~g} / \mathrm{L} \mathrm{G} 418$ (Invitrogen) for $2 \mathrm{~d}$ to reach full confluence. Subsequently, the medium was replaced by hybridoma serum-free medium (Invitrogen), and cells incubated for additional $3 \mathrm{~d}$ $\left(37^{\circ} \mathrm{C}, 5 \% \mathrm{CO}_{2}\right)$. Conditioned Reelin and control (GFP) medium was collected and finally centrifuged $(4000 \times g, 5 \mathrm{~min})$ before storing at $-80^{\circ} \mathrm{C}$.

\section{Preparation of hippocampal slice cultures}

Brains of P6 wild-type mice and reeler mutants ( $n=5$ each) were sliced $(300 \mu \mathrm{m})$ with a McIlwain tissue chopper. Slices were transferred onto Millipore membranes and placed into six-well plates with $1.2 \mathrm{ml} /$ well nutrition medium (25\% heat-inactivated horse serum, 25\% HBSS, 50\% minimal essential medium, 2 mm glutamine, $\mathrm{pH}$ 7.2). Slices were incubated as static cultures in $5 \% \mathrm{CO}_{2}$ at $37^{\circ} \mathrm{C}$ for $7 \mathrm{~d}$ in vitro (Stoppini et al., 1991). The medium was changed every $2 \mathrm{~d}$.

For treatment of cultures with Reelin, $200 \mu \mathrm{l}$ of conditioned Reelin or control medium was added every second day to each well containing $1 \mathrm{ml}$ of normal nutrition medium. In addition, $3 \mu \mathrm{l}$ of supernatant was directly applied onto each slice when the medium was replaced for the first time. The RGD motive-containing integrin inhibitor peptide [cyclo(ArgGly-Asp-D-Phe-Val); 182015; Merck Chemicals] was added to the nutrition medium at a final concentration of $150 \mu \mathrm{M}$. The Reelin blocking antibody CR-50 (Ogawa et al., 1995) was applied to the nutrition medium at a final concentration of $200 \mu \mathrm{g} / \mathrm{ml}$; treatment was performed as described for Reelin. After 6 d in culture, slices were centrifuged $(800 \times$ $g$, $5 \mathrm{~min}, \mathrm{RT}$ ), supernatants were discarded, and the tissue was immediately frozen in liquid nitrogen and stored at $-80^{\circ} \mathrm{C}$.

\section{Electron microscopy}

Fixation. Adult mouse brains were fixed as described previously (Deller et al., 2000). Coronal sections $(100 \mu \mathrm{m})$ of the hippocampal region were embedded, serially thin-sectioned, and processed for electron microscopy. For studies on organotypic slices, hippocampal slice cultures $(n=$ 3 for each condition) were fixed with $4 \%$ paraformaldehyde and $2.5 \%$ glutaraldehyde in $25 \mathrm{~mm}$ PBS for $60 \mathrm{~min}$.

Processing sections for electron microscopy. Sections were treated with $1 \%$ osmium tetroxide in $0.1 \mathrm{~m}$ phosphate buffer $(\mathrm{PB})$ for $40 \mathrm{~min}$ at room temperature in the dark, washed in $\mathrm{PB}$ and double-distilled water, and contrasted in $1 \%$ uranyl acetate for $40 \mathrm{~min}$. Sections were dehydrated in a series of ethanol, followed by propylene oxide. After $1 \mathrm{~h}$ incubation in a propylene oxide-epoxy resin mixture (Durcopan ACM; Sigma-Aldrich; $1: 1$ ), sections were incubated in Durcopan overnight and flat embedded. After polymerization for $2-3 \mathrm{~d}$ at $60^{\circ} \mathrm{C}$, sections were cut at $50 \mathrm{~nm}$ thickness using an ultramicrotome (Reichert Ultracut E; Leica).

Data acquisition and statistical analysis. Ultrathin sections were visualized with a LEO 906E electron microscope (Zeiss). Measurements were performed with commercially available image analysis software (AnalySIS; SIS). For ultrastructural analysis of CA1 stratum radiatum synapses, the following parameters were obtained: number of boutons and number of vesicles per bouton area. A structure was considered a presynaptic bouton if at least three synaptic vesicles were clearly visible and a synaptic membrane specialization was present. At least 100 synapses per animal ( $n=4$ for each genotype, $n=3$ for Reelin-treated cultures) in stratum radiatum of CA1 were analyzed. Statistical analysis was performed by using the nonparametric Mann-Whitney $U$ test. Significance was assigned for all tests at $p<0.05$.

SDS-digested freeze-fracture replica immunolabeling. Adult Wistar rats $(n=3)$ purchased from Charles River were deeply anesthetized with sodium pentobarbital (50 mg/kg, i.p.) and transcardially perfused with $2 \%$ paraformaldehyde and $15 \%$ saturated picric acid in $0.1 \mathrm{M} \mathrm{PB}, \mathrm{pH} 7.4$. Coronal sections $(90 \mu \mathrm{m})$ of the CA1 area were cut on a vibratome (Leica). After cryoprotection in $30 \%$ glycerol in $0.1 \mathrm{M} \mathrm{PB}$ overnight at $4^{\circ} \mathrm{C}$, the sections were frozen by a high-pressure freezing machine (HPM 100; Leica). Frozen samples were inserted into a double replica table and fractured into two pieces at $-130^{\circ} \mathrm{C}$. Fractured faces were replicated by deposition of carbon ( $5 \mathrm{~nm}$ thickness), platinum ( $2 \mathrm{~nm})$, and carbon (20 $\mathrm{nm}$ ) in a freeze-fracture replica machine (BAF 060; Bal-Tec). They were 
incubated in $2.5 \%$ SDS, $20 \%$ sucrose in $15 \mathrm{~mm}$ Tris buffer, $\mathrm{pH} 6.8$, at $80^{\circ} \mathrm{C}$ overnight. The replicas were washed in $25 \mathrm{~mm}$ Tris-buffered saline (TBS) containing $0.05 \%$ bovine serum albumin (BSA) and incubated in a blocking solution containing 5\% BSA in $25 \mathrm{~mm}$ TBS for $1 \mathrm{~h}$. Subsequently, the replicas were incubated with a mixture of primary antibodies $(20-25 \mu \mathrm{g} / \mathrm{ml})$ for SNAP25 (111001; Synaptic Systems) and $\beta 1$-integrin (AB1952; Millipore) diluted in TBS containing 5\% BSA overnight at RT. After several washes, the replicas were incubated with gold-coupled goat anti-rabbit (for $\beta 1$-integrin) and goat anti-mouse (for SNAP25) secondary antibodies (1:30; BioCell Research Laboratories) made up in $25 \mathrm{~mm}$ TBS containing 5\% BSA overnight at RT. They were then washed and picked up on 100 mesh grids. Micrographs were taken with an ORIUS SC600 digital camera (Gatan) at a Philips CM 100 electron microscope.

\section{Electrophysiology}

Animals and tissue preparation. Five wild-type and four reeler mice, aged 24-50 d, were decapitated after being deeply anesthetized with Forene (Abbott). Their brains were instantly removed and immersed in ice-cold artificial CSF (ACSF). Horizontal $300 \mu \mathrm{m}$ slices were cut using a DSK 1000 Vibratome (Dosaka) and incubated subsequently at $37^{\circ} \mathrm{C}$ for a minimum of $40 \mathrm{~min}$ in low-calcium ACSF solution equilibrated with $95 \% \mathrm{O}_{2}$ and $5 \% \mathrm{CO}_{2}$. For electrophysiological studies, slices were transferred to a recording chamber perfused with standard ACSF solution at a rate of 2-3 $\mathrm{ml} / \mathrm{min}$. The standard ACSF was composed of the following (in mM): 125 $\mathrm{NaCl}, 25 \mathrm{NaHCO}_{3}, 25$ glucose, $2.5 \mathrm{KCl}, 1.25 \mathrm{NaH}_{2} \mathrm{PO}_{4}, 2 \mathrm{CaCl}_{2}$, and 1 $\mathrm{MgCl}_{2}$, equilibrated with $95 \% \mathrm{O}_{2}$ and $5 \% \mathrm{CO}_{2}$; in the low-calcium ASCF, the concentration of $\mathrm{CaCl}_{2}$ was reduced to $0.5 \mathrm{~mm}$ and that of $\mathrm{MgCl}_{2}$ was increased to $4 \mathrm{~mm}$. All experiments were performed at $32-34^{\circ} \mathrm{C}$.

Extracellular recordings. Extracellular field potentials were recorded using an Axopatch 200B amplifier (Molecular Devices) in fast currentclamp mode. The recordings were filtered at $10 \mathrm{kHz}$ using the four-pole low-pass Bessel filter of the amplifier and digitized at $20 \mathrm{kHz}$. Clampex 9.2.0.9 (Molecular Devices) running on a Pentium PC was used for data acquisition. Stimuli were generated by a DS3 constant current isolated stimulator (Digitimer). Pipettes for recording and stimulation were pulled from borosilicate glass tubing ( $2 \mathrm{~mm}$ outer diameter, $1 \mathrm{~mm}$ inner diameter) on a Sutter P-87 puller (Sutter Instrument) and filled with HEPES-buffered physiological $\mathrm{NaCl}$ solution; resistance of the filled pipettes ranged from 0.34 to $1.1 \mathrm{M} \Omega$. Both stimulation and recording electrodes were positioned in the outer third of the CA1 stratum radiatum, $\sim 50 \mu \mathrm{m}$ apart. Extracellular field potentials were evoked by paired stimulus pulses with an interstimulus interval of $50 \mathrm{~ms}$ at a frequency of $0.1 \mathrm{~Hz}$. For all recordings, the stimulus duration was $0.1 \mathrm{~ms}$ and the intensity was varied systematically in the range of 10 to $200 \mu \mathrm{A}$ (nominal values).

Data analysis. Amplitudes of the field EPSPs (fEPSPs) were measured as the difference between the voltage level immediately preceding the onset and the negative peak of the fEPSP. To normalize the differences between wild-type animals and reeler mice, the paired-pulse facilitation ratio (PPR) was calculated from the averaged traces by dividing the amplitude of the second fEPSP by that of the first fEPSP. Stability of the recording was controlled regularly by test pulses of constant amplitude. Only experiments with changes $<20 \%$ in the test fEPSP amplitude were accepted.

Statistics. Calculations were performed in Microsoft Office Excel 2003 (Microsoft) and Matlab 7.1 (The MathWorks). Values are given as mean \pm SEM. The significance of differences in individual amplitudes and PPF indices was assessed by a nonparametric statistical test for independent samples, the Mann-Whitney $U$ test.

\section{Results}

Synapses of reeler mice exhibit an increase in vesicle number We studied the ultrastructure of presynaptic boutons in stratum radiatum of hippocampal region CA1 in adult wild-type and reeler mice ( $n=4$ animals for each genotype). In view of the altered anatomy of CA1 in the reeler mutant with a duplication of the pyramidal cell layer, we first counted the number of presynaptic boutons in comparable areas of CA1 in reeler and wild-type
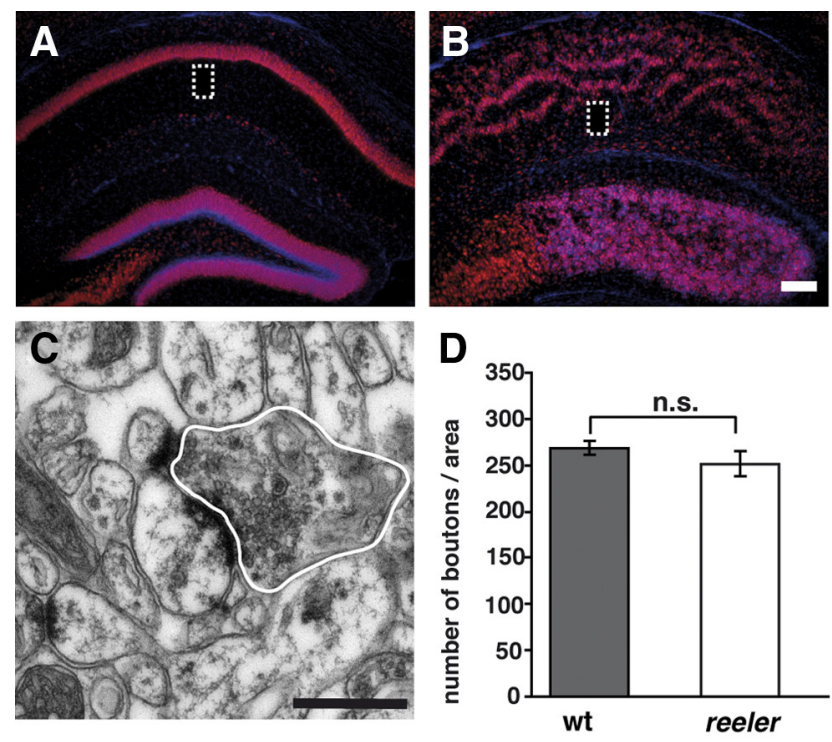

E

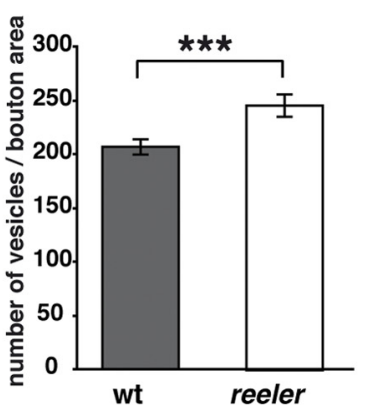

$\mathbf{F}$

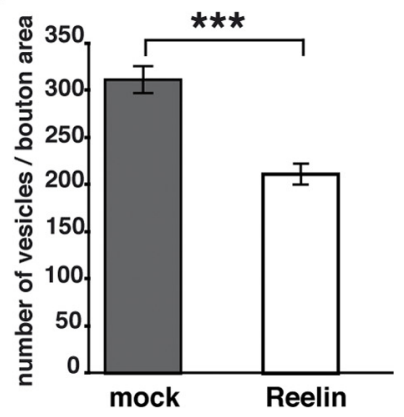

Figure 1. Ultrastructural analysis of presynaptic boutons in CA1 stratum radiatum. $\boldsymbol{A}, \boldsymbol{B}$, NeuN/DAPI staining on coronal brain sections through the hippocampus of adult wild-type (wt) animals $(\boldsymbol{A})$ and reeler mice $(\boldsymbol{B})$ reveal the characteristic altered anatomical organization of CA1 in the reeler hippocampus. The boxes indicate regions of the CA1 stratum radiatum where ultrastructural analyses of presynaptic boutons were performed. $\boldsymbol{C}$, Representative electron micrograph of a presynaptic bouton in CA1 stratum radiatum. Bouton profiles were marked (white line) and the area measured. D, Number of boutons per area neuropil in CA1 stratum radiatum. No significant differences between wild-type mice and reeler mutants were observed. $\boldsymbol{E}$, Counting the number of vesicles per bouton area (in square micrometers) showed a significant increase in reeler mice when compared with wild-type animals. $\boldsymbol{F}$, Incubation of organotypic slice cultures from P6 reeler hippocampi in the presence of recombinant Reelin significantly decreased the number of vesicles per bouton area (in square micrometers) when compared with mock-treated cultures. Scale bars: $\boldsymbol{A}, \boldsymbol{B}, 200 \mu \mathrm{m} ; \boldsymbol{C}, 500 \mathrm{~nm}$. Data are expressed as mean \pm SEM; Mann-Whitney $U$ test: ${ }^{* *} p<0.001$; n.S., not significant.

mice (Fig. 1 $A-D$ ) and did not observe statistically significant differences between genotypes (Fig. 1D) (number of boutons: wild-type animals, $267 \pm 9$ SEM; reeler mutants, $251 \pm 13$ SEM; $p=0.44$; Mann-Whitney $U$ test). However, when analyzing vesicle numbers, significant differences were observed. We found that reeler mutants exhibited an increase in the number of vesicles per bouton area by $\sim 20 \%$ compared with wild-type animals (Fig. $1 E$ ) [vesicles per bouton area (in $\mu \mathrm{m}^{2}$ ): wild-type animals, $207 \pm$ 6 SEM; reeler, $246 \pm 8$ SEM; $p=0.0001 ; 100$ boutons per animal; Mann-Whitney $U$ test]. These data indicate that, in reeler mutants, either more vesicles are produced or less released.

Reelin treatment diminishes vesicle density at reeler synapses We found significantly more vesicles in the reeler hippocampal region CA1 compared with wild-type animals. To address the question whether this effect is a direct and reversible consequence of the lack of Reelin, we treated organotypic slice cultures of P6 
A

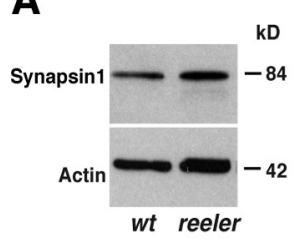

B

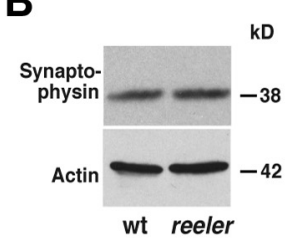

C
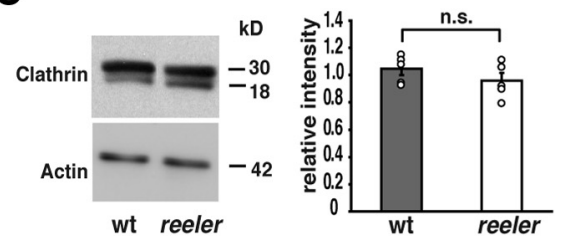

D
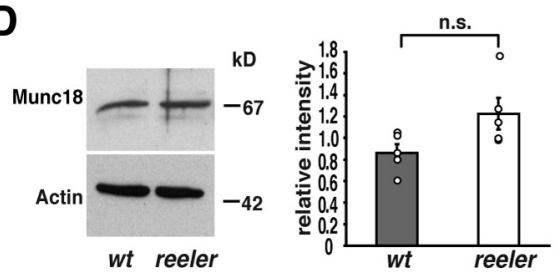

E

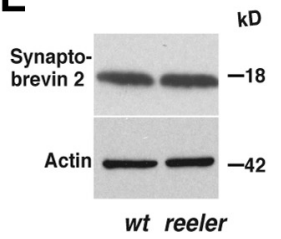

$\mathbf{F}$

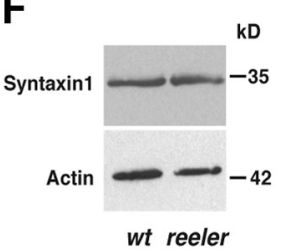

G

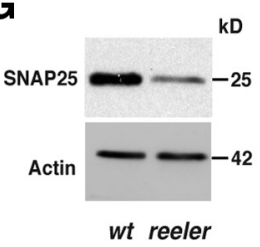

Figure 2. Expression of presynaptic proteins. Quantitative Western immunoblot analysis of presynaptic proteins was performed with membrane fractions of hippocampal and cortical tissue of adult wild-type mice (wt) and reeler mutants. $\boldsymbol{A}-\mathbf{G}, \mathrm{N}_{0}$ significant differences were observed between reeler mutants and wild-type animals in protein levels of synapsin1 $(\boldsymbol{A})$, synaptophysin $(\boldsymbol{B})$, and clathrin light chain $(\boldsymbol{C})$, Munc18 (D), synaptobrevin $(\boldsymbol{E})$, and syntaxin $1(\boldsymbol{F})$. In contrast, expression levels of SNAP25 $(\boldsymbol{G})$ were significantly decreased in tissue of reeler mutants when compared with wild-type mice. Densitometric analysis was performed in five independent experiments. Data are expressed as mean \pm SEM. The circles show individual values. Unpaired Student's $t$ test: ${ }^{*} p<0.05 ;{ }^{* *} p<0.01 ;$ n.S., not significant.

reeler hippocampi with recombinant Reelin ( $n=3$ animals). The ultrastructural analysis of synapses in CA1 $(n=200$ per condition) revealed a significant decrease in the number of vesicles per bouton area in Reelin-treated reeler cultures. No decrease in vesicle number was observed in mock-treated tissues (Fig. $1 F$ ) [vesicles per bouton area (in $\mu \mathrm{m}^{2}$ ): Reelin-treated cultures, $211 \pm 11$ SEM; mocktreated cultures, $312 \pm 14$ SEM; $p<0.001$; Mann-Whitney $U$ test].

\section{SNAP25 is decreased in reeler mice}

To test the hypothesis that an increased number of synaptic vesicles in reeler mutants may reflect altered vesicle fusion, the expression of a variety of synaptic proteins known to be involved in vesicle generation, fusion, stabilization, and recycling were analyzed in cortical and hippocampal tissues of adult wild-type mice and reeler mutants using Western immunoblotting (at least five animals per genotype; one experiment per animal and protein).

\section{Vesicle-associated proteins}

Synapsin 1, synaptophysin, and the clathrin light chain were studied as proteins associated with synaptic vesicles. These molecules were chosen because of their key functions during endocytosis and exocytosis. Synapsin 1 is essential for accelerating vesicle traffic during repetitive stimulation and the maintenance of normal vesicle numbers (Hilfiker et al., 1999; Südhof, 2004). Synaptophysin is involved in correct vesicle recycling (Valtorta et
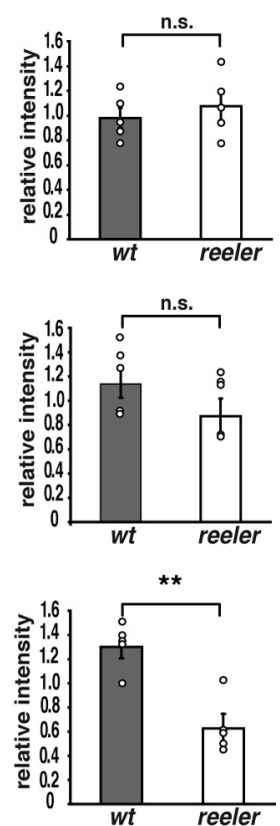

al., 2004) and clathrin in vesicle recycling and endocytosis (Maycox et al., 1992). Our Western blot analysis showed that the protein levels of these molecules were not significantly altered between reeler and wild-type animals (Fig. $2 A-C$ ) (relative intensities: synapsin 1: wild-type animals, $1.07 \pm 0.13$ SEM; reeler, $0.91 \pm 0.15$ SEM; $p=0.45$; synaptophysin: wild-type animals, $1.0 \pm 0.1$ SEM; reeler, $1.08 \pm 0.13$ SEM; $p=0.63$; clathrin: wild-type animals, $1.05 \pm 0.04$ SEM; reeler, $0.96 \pm 0.13$ SEM; $p=0.27$; unpaired Student's $t$ test).

SNARE and SNARE-associated proteins Next, we analyzed SNARE complex proteins, which are known to control vesicle fusion (Parpura and Mohideen, 2008), and the SNARE-associated protein Munc18. For Munc18-1, known to stabilize the conformation of syntaxin so that it is capable of forming SNARE complexes (Zilly et al., 2006), no significant differences in protein expression were found between wild-type and reeler animals, although there was a slight tendency toward increased values in the mutant (Fig. 2D) (relative intensities: wild-type animals, $0.86 \pm 0.08$ SEM; reeler, $1.23 \pm 0.15 \mathrm{SEM}$; $p=0.06$; unpaired Student's $t$ test). Similar results were obtained for synaptobrevin and syntaxin 1 , proteins of the SNARE complex (Fig. 2E,F) (synaptobrevin: wild-type animals, $0.98 \pm 0.08$ SEM; reeler, $1.07 \pm 0.12 \mathrm{SEM} ; p=0.53$; syntaxin 1: wild-type animals, $1.14 \pm 0.12$ SEM; reeler, $0.87 \pm 0.14$ SEM; $p=0.18$ ). Current models suggest that these proteins form a tight complex with the plasma membrane during synaptic vesicle fusion (Hanson et al., 1997). Of note, we found a significant decrease in the expression of SNAP25 (Fig. 2G) (wild-type animals, $1.3 \pm 0.1 \mathrm{SEM}$; reeler, $0.63 \pm 0.11$ SEM; $p=0.001$ ). Together with our findings of an increased number of vesicles in presynaptic boutons, the significant decrease in the expression of SNAP25 points to an alteration in vesicle fusion in reeler mutants.

\section{Reelin blocking antibodies reduce SNAP25 expression in wild-type slice cultures and increase presynaptic vesicle numbers}

Our finding that SNAP25 as part of the SNARE complex is altered in reeler mutants raises the question as to whether this is a consequence of an altered extracellular matrix and cytoarchitecture resulting from perturbed brain development. Therefore, we used CR-50 anti-Reelin antibodies (Ogawa et al., 1995) to neutralize Reelin function in wild-type organotypic slice cultures of P6 animals $(n=3)$. Our Western immunoblot analysis showed that exogenous CR-50 treatment decreased SNAP25 protein in hippocampal wild-type cultures compared with mock-treated cultures (Fig. $3 A, B$ ) (relative intensities: CR-50-treated cultures, $0.44 \pm 0.2$ SEM; mock-treated cultures, $1.34 \pm 0.09$ SEM; $p=$ 0.01 ; unpaired Student's $t$ test). To test whether blocking of Reelin in wild-type tissue also affects the number of presynaptic 
vesicles as observed in reeler animals, we treated again wild-type organotypic cultures with CR-50 antibodies and performed ultrastructural analyses of synapses in CA1 ( $n=3$ animals; at least 100 boutons per condition and animal). In accordance with our previous results, we found a significant increase in the number of vesicles per bouton area in CR50-treated cultures (Fig. 3C) [vesicles per bouton area (in $\mu \mathrm{m}^{2}$ ): CR-50-treated cultures, $158 \pm 3$ SEM; mock-treated cultures, $124 \pm 4$ SEM; $p<0.001$; MannWhitney $U$ test]. These results together suggest that a developmental reeler phenotype does not account for the observed increase in vesicle number and SNAP25 downregulation in the adult reeler hippocampus.

\section{Expression of SNAP25 is not decreased in ApoER2 mutants, VLDLR mutants, receptor double knock-out mice, and Dab1 mutants}

Our results indicate that Reelin is involved in the regulation of SNAP25 expression, a presynaptic protein and member of the SNARE complex. How is this Reelin effect mediated? To test whether the canonical Reelin signaling cascade is involved in these processes, we studied the expression of SNAP25 in hippocampal and cortical tissue of ApoER2 ${ }^{-1-}, V L D L R^{-/-}$single and double knock-out mice as well as in Dab1-deficient animals ( $n=3-4$ animals per genotype, one experiment per animal and protein). We were unable to find a significant decrease in SNAP25 when comparing lysates of control animals and these mutant mice (Fig. $3 D, E$ ) (relative intensities: controls, $0.93 \pm$ $0.12 \mathrm{SEM} ;$ ApoER2 ${ }^{-l-}, 1.12 \pm 0.14 \mathrm{SEM} ; p=0.35$; controls, $0.89 \pm 0.08$ SEM; VLDLR ${ }^{-/-}, 1.21 \pm 0.14$ SEM; $p=0.09$; controls, $0.9 \pm 0.06 \mathrm{SEM}$; Dab1 $1^{-l-}, 1.12 \pm 0.06 \mathrm{SEM} ; p=0.05$; controls, $0.91 \pm 0.06$ SEM; ApoER2 $2^{-/-} / V L D L R^{-/-}, 1.1 \pm 0.03$ SEM; $p=0.004$; unpaired Student's $t$ test).

\section{Rescue of SNAP25 protein expression in slice cultures of reeler mutants by exogenous Reelin}

To examine whether recombinant Reelin is capable to restore the expression levels of SNAP25 in tissues of reeler mutants in vitro, we treated organotypic slice cultures of $\mathrm{P} 6$ reeler hippocampi with recombinant Reelin ( $n=3$ animals, one experiment per animal and condition). Similar to our previous experiments in which exogenous Reelin was able to normalize vesicle number, recombinant Reelin rescued SNAP25 protein levels. Western immunoblot analysis showed that exogenous Reelin increased the level of SNAP25 protein in slice cultures of reeler hippocampus compared with mock-treated cultures (Fig. 4A,B) [relative intensities: Reelin-treated cultures (Reelin), $1.42 \pm 0.05$ SEM; mock-treated cultures (mock), $0.75 \pm 0.15$ SEM; $p=0.03$; unpaired Student's $t$ test].

\section{Integrin inhibitor peptides neutralize the rescue effect of Reelin}

Western blot analyses of ApoER2, VLDLR, and Dab1 null mutant mice suggested a noncanonical Reelin signaling pathway in the
B

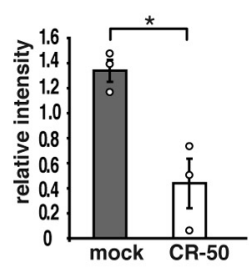

C

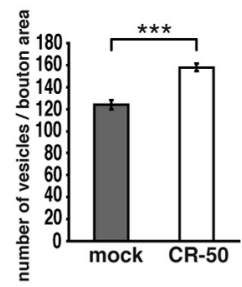

E

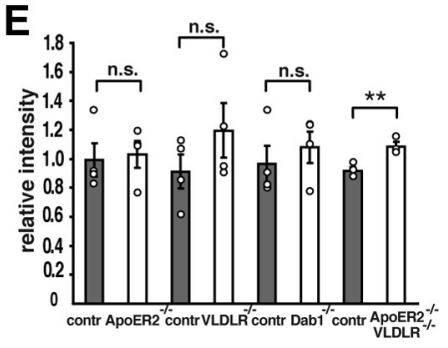

Figure 3. Analysis of SNAP25 protein levels in CR-50-treated wild-type cultures and mutants deficient in the canonical Reelin 列 SEM. Circles show individual values. Unpaired Student's $t$ test $(\boldsymbol{B}, \boldsymbol{E})$ and Mann-Whitney $U$ test $(\boldsymbol{C}):{ }^{*} p<0.05 ;{ }^{* *} p<0.01$;

regulation of SNAP25 protein levels. Previous studies have demonstrated that the N-terminal region of Reelin binds $\alpha 3 \beta 1$ integrin (Dulabon et al., 2000; Förster et al., 2002; Schmid et al., 2005). To test whether Reelin-integrin interactions may contribute to the presynaptic effects of Reelin, an integrin inhibitor peptide (Shono et al., 2001) was added to organotypic slice cultures of reeler hippocampi treated with recombinant Reelin $(n=3$ animals, one experiment per animal and condition). Our subsequent Western immunoblot analysis showed that the rescue effect of Reelin on SNAP25 was abolished in the presence of RGD motive-containing integrin inhibitor peptides, whereas addition of integrin inhibitor peptides to mock-treated tissue had no significant effect (Fig. 4A,B) (relative intensities: Reelin-treated cultures (Reelin), $1.42 \pm 0.05$ SEM; Reelin plus integrin inhibitortreated cultures (Reelin plus RGD), $0.65 \pm 0.1$ SEM; mock plus integrin inhibitor-treated cultures (mock plus RGD), $1.28 \pm 0.17$ SEM; Reelin vs Reelin plus RGD, $p=0.0051$; mock vs mock plus RGD, $p=0.12$; unpaired Student's $t$ test).

\section{Integrin inhibitor treatment increases vesicle density at} wild-type synapses

We found that RGD inhibitor peptides are capable of blocking the Reelin effect on presynaptic vesicle density in reeler mutant slice cultures. To test whether RGD inhibitor peptides might also regulate vesicle density at wild-type synapses, we treated organotypic slice cultures of P6 wild-type hippocampi with RGD and control peptides and analyzed vesicle density in synaptic boutons by electron microscopy $(n=5$ animals, 100 boutons per animal and condition). We found that also in wild-type slice cultures RGD peptides were able to significantly increase vesicle densities in accordance with our findings in the reeler mutant when compared with control peptide-treated slice cultures (Fig. 4C) [vesicles per bouton area (in $\mu \mathrm{m}^{2}$ ): integrin inhibitor- 
A

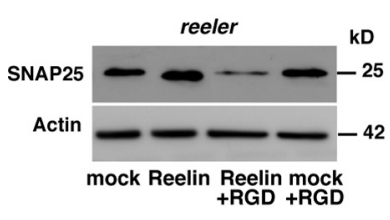

B

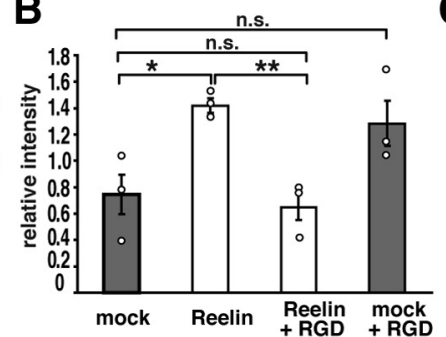

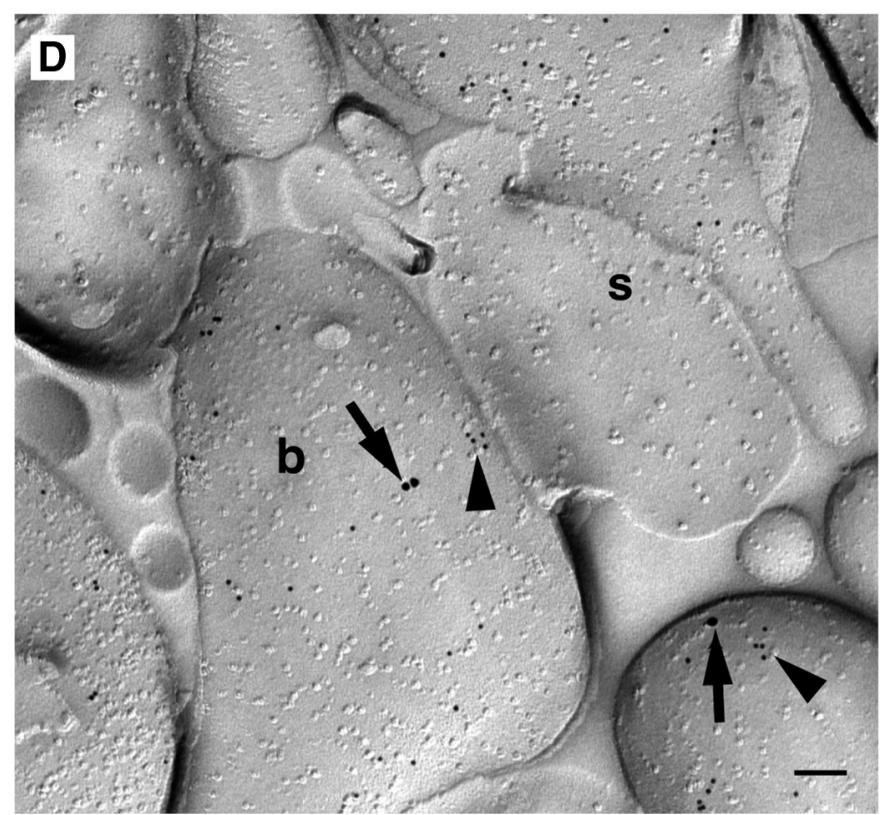

Figure 4. Recombinant Reelin rescues SNAP25 expression in slice cultures from reeler mice, and integrin inhibitor neutralizes this effect. $A$, Incubation of organotypic slice cultures from P6 reeler hippocampi in the presence of recombinant Reelin significantly increased protein expression of SNAP25 compared with lysates of mock-treated cultures. Addition of RGD motive-containing integrin inhibitor peptides abolished the rescue effect of Reelin on SNAP25 expression (Reelin plus RGD). B, Densitometric analysis was performed in at least three independent experiments. C, RGD integrin inhibitor peptides significantly increased the number of vesicles per bouton area (in square micrometers) when compared with control peptide-treated cultures (control). Data are expressed as mean \pm SEM. The circles show individual values. Unpaired Student's $t$ test $(\boldsymbol{B})$ and Mann-Whitney $U$ test $(\boldsymbol{C}):{ }^{*} p<$ $0.05 ;{ }^{* *} p<0.01 ;{ }^{* * *} p<0.001$; n.s., not significant. $\boldsymbol{D}$, Double immunogold labeling for $\beta 1$-integrin ( $15 \mathrm{~nm}$ particles; arrows) and SNAP25 (10 nm; arrowheads) revealed localization in presynaptic boutons (b) of CA1 stratum radiatum. S, Postsynaptic element, likely a dendritic spine. Scale bar, $100 \mathrm{~nm}$.

treated cultures (RGD), $153 \pm 3$ SEM; mock-treated control cultures, $129 \pm 3$ SEM; $p<0.001$; Mann-Whitney $U$ test $]$.

\section{Presynaptic localization of $\beta 1$-integrin in CA1 synapses}

To investigate the localization of $\beta 1$-integrin in subcellular compartments of CA1 neurons, we performed electron microscopic immunocytochemistry. By performing SDS-digested freeze-fracture replica immunolabeling (Hagiwara et al., 2005; Kulik et al., 2006), we found $\beta 1$-integrin in presynaptic compartments of CA1 synapses. Anti-SNAP25 labeling was used to identify presynaptic compartments (Fig. 4D). Counting the number of $\beta 1$-integrin/SNAP25 double-positive presynaptic boutons in relation to the total number of SNAP25-labeled synapses revealed that $48 \%$ of SNAP25-positive boutons were also labeled for $\beta 1$-integrin $(n=3$ animals; 294 SNAP25-positive boutons; 143 SNAP25/ $\beta 1$-integrin doublepositive boutons).

\section{PPF at Schaffer collateral synapses is reduced in reeler}

To study whether the observed changes in vesicle number and SNAP25 protein levels in reeler mutants result in a presynaptic transmission phenotype, extracellular recordings in acute hippocampal

C

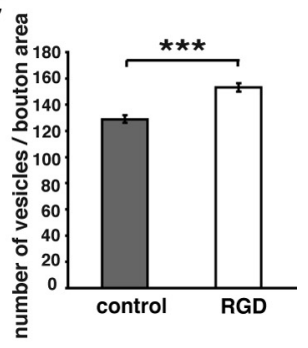

slices from wild-type animals and reeler mice were performed in stratum radiatum ofCA1. Stimulation of the Schaffer-collaterals elicited a brief presynaptic fiber volley followed by a fEPSP in both acute slices from wild-type animals and reeler mutants (Fig. 5A). Although the waveforms of the responses were similar between reeler and wild-type tissues, the amplitudes of the fEPSPs were smaller in slices from reeler mice for all stimulus intensities $>25 \mu \mathrm{A}$ (Fig. $5 B$ ) $(p<0.1)$. The lower fEPSP amplitude can be partially explained by the altered lamination of the reeler hippocampus, but may also point to a compromised synaptic transmission in these animals.

Next, we analyzed synaptic responses to paired-pulse stimuli. In wild-type animals, two consecutive pulses with an interpulse interval of $50 \mathrm{~ms}$ resulted in a facilitation of the second synaptic response (Fig. $5 A, C$ ). PPR was 1.7 at 12.5 $\mu \mathrm{A}$, but rapidly decreased with increasing stimulus intensity, reaching a minimal value of 1.29 at $200 \mu \mathrm{A}$. In contrast, only moderate PPF or even paired-pulse depression was observed in reeler slices at low stimulus intensities as reflected by the low average PPR of 1 at $12.5 \mu \mathrm{A}$. At higher stimulus intensities, depression was replaced by a moderate degree of PPF. As the wild-type PPR approached saturation, the reeler PPR converged to, but remained below that of wild-type animals for the entire range (Fig. 5C). These differences in PPR were significant for all statistically evaluated stimulus intensities ( $25 \mu \mathrm{A}, p=0.0055$; $50 \mu \mathrm{A}, p=0.0111 ; 75 \mu \mathrm{A}, p=0.0037$; $100 \mu \mathrm{A}, p=0.0152 ; 150 \mu \mathrm{A}, p=0.0152$ $200 \mu \mathrm{A}, p=0.0464)$.

These results suggest that synaptic transmission is reduced and presynaptic release mechanisms are altered in reeler mice.

\section{Discussion}

The results of the present study reveal a novel, presynaptic function of Reelin in the mature brain. They can be summarized as follows. (1) Presynaptic boutons of synapses in stratum radiatum of CA1 contain a larger number of synaptic vesicles in reeler mutants than in wild-type mice. (2) SNAP25, a protein of the SNARE complex, is significantly decreased in reeler mutants when compared with wild-type mice. Other SNARE proteins and synaptic vesicle proteins appear mostly unchanged. (3) PPF, a form of presynaptic plasticity depending on vesicle release, is impaired at synapses in stratum radiatum of CAl.

Together, these findings point to altered vesicle fusion and neurotransmitter release at Schaffer collateral synapses in adult reeler mutants and demonstrate a role for Reelin in regulating presynaptic functions. The results may have implications for a variety of neuropsychiatric diseases known to be associated with altered Reelin expression such as schizophrenia, bipolar disorder, and major depression (Impagnatiello et 


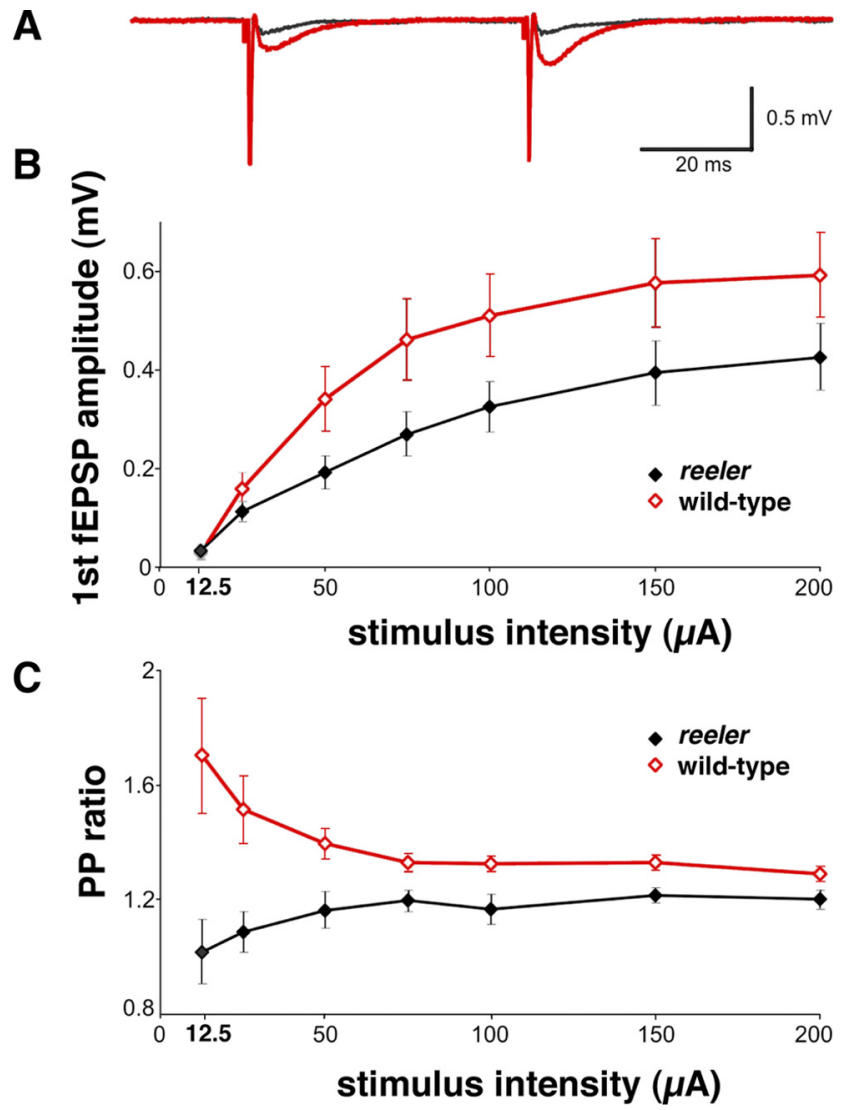

Figure 5. Extracellular recordings in CA1 show changes in reeler fEPSP amplitude and PPF.A, Typical fEPSPs from wild-type and reeler mice in hippocampal slices recorded at $50 \mu$ A stimulus intensity and $50 \mathrm{~ms}$ interpulse interval illustrate the reduced amplitude in reeler fEPSP (black) compared with wild-type fEPSPs (red). In contrast to reeler, pronounced PPF was elicited in wild-type slices after the second pulse. The recordings contain a distinct fiber volley immediately after the stimulus (stimulation artifacts truncated). fEPSP amplitude ( $\boldsymbol{B}$ ) and fEPSP pairedpulse ratio $(\boldsymbol{C})$ are significantly reduced in slices from reeler mice $(n=9)$ compared with wild-type slices $(n=8)$. At the lowest stimulus intensity $(12.5 \mu \mathrm{A})$, synaptic responses could be detected in only five reeler slices and four wild-type slices. Data are expressed as mean \pm SEM.

al., 1998; Fatemi et al., 2000; Eastwood and Harrison, 2003; Grayson et al., 2005), epilepsy (Haas et al., 2002), as well as Alzheimer's disease (Botella-López et al., 2006), a disease of the aged human brain.

Numerous studies have confirmed an essential role for Reelin in the development of the CNS (see Introduction). Consequently, functional deficits associated with decreased Reelin expression have been attributed to developmental defects (Eastwood and Harrison, 2003). However, malexpression of Reelin in neuropsychiatric diseases of adult or aged human beings points to additional functions of Reelin. Indeed, evidence has accumulated in recent years that Reelin is also involved in neuronal functions in the mature brain. First, it was noticed that Reelin, which in the prenatal period is expressed by CR cells in the marginal zone, is expressed by a variety of GABAergic interneurons in the postnatal brain (Drakew et al., 1998; Pesold et al., 1998). Second, Beffert et al. (2005) have shown that modulation of synaptic plasticity and memory by Reelin involves differential splicing of ApoER2 and interaction with the NMDA receptor complex. Third, in a study on the molecular determinants of granule cell dispersion, a loss of the normal dense packing of dentate granule cells in epilepsy, Heinrich et al. (2006) provided evidence for a role of Reelin in the maintenance of cortical architecture in the adult brain.
The present study adds another piece of evidence to a role of Reelin in the mature brain. We show here that the number of synaptic vesicles in presynaptic boutons of CA1 is significantly larger in reeler mutants when compared with wild-type littermates. Together with the significantly decreased protein expression of SNAP25, an essential component of the SNARE complex controlling vesicle fusion, these results point to compromised fusion and transmitter release. This conclusion is supported by the observation of severely altered paired-pulse facilitation, a form of presynaptic plasticity associated with increased transmitter release, in reeler mutant animals.

What could be the role of Reelin in vesicle fusion and transmitter release? It seems unlikely that developmental defects caused by altered neuronal migration and aberrant connectivity underlie the altered PPF in slices from reeler mutants. First, PPF was also found impaired in heterozygous reeler mice (Qiu et al., 2006) that do not show developmental defects in anatomical organization. Second, counts of presynaptic boutons in stratum radiatum of CA1 did not reveal significant differences to wildtype animals, whereas individual boutons showed a significantly increased number of synaptic vesicles. Third, incubation of reeler tissue in the presence of recombinant Reelin was able to rescue protein levels of SNAP25 and reduced the number of vesicles in presynaptic boutons. Fourth, blocking Reelin function by CR-50 antibodies in slice cultures of wild-type animals resulted in an increase in presynaptic vesicles and in a reduction in SNAP25 protein, similar to our findings in reeler mutants. We conclude that Reelin, probably in concert with other molecules of the extracellular matrix, is involved in presynaptic mechanisms of transmitter release.

What could be the molecular pathways leading to decreased SNAP25 protein levels in reeler mutants? Recent studies have shown that the transcription factor SP1 regulates SNAP25 gene expression and that the human SNAP25 gene promoter contains functional SP1 response elements. Overexpression of SP1 increased SNAP25 gene expression (Cai et al., 2008). Interestingly, SP1 is involved in the induction of the Reelin promoter by retinoic acid (Chen et al., 2007), pointing to a network that interconnects the expression of an extracellular matrix protein and a SNARE protein. However, when we studied SP1 protein in reeler mutants compared with wild-type animals, we did not find a significant difference to wild-type tissue (data not shown). Additional studies are required to determine the various players involved in Reelin-dependent SNAP25 expression.

PPF is a form of presynaptic plasticity mediated by increased, $\mathrm{Ca}^{2+}$-induced neurotransmitter release (Wu and Saggau, 1994; Rozov et al., 2001). Previous studies revealed a role for Reelin in the differentiation and function of postsynaptic structures, such as dendrites, spines, and the postsynaptic density (Niu et al., 2004, 2008; Beffert et al., 2005). Long-term potentiation was found differentially modulated by splice variants of ApoER2 located at the postsynaptic density (Beffert et al., 2005). Of note, SNAP25 expression was not altered in ApoER2, VLDLR single and double knock-out mice, and Dab1 ${ }^{-1-}$ mutants, suggesting that canonical Reelin signaling via lipoprotein receptors and Dab1 is not involved in the effects of Reelin on vesicle fusion and transmitter release.

In addition to signaling via lipoprotein receptors and Dab1, Reelin is known to bind $\alpha 3 \beta 1$-integrins (Dulabon et al., 2000; Förster et al., 2002). Integrins comprise a large family of cell adhesion molecules that mediate signaling between cells, are broadly expressed in the brain, and are associated with synapses. Moreover, integrins are required for hippocampal synaptic plas- 
ticity and spatial memory (Chan et al., 2003). Remarkably, reduced expression of $\alpha 3$-integrins results in a defect in PPF (Chan et al., 2003), and integrin-associated protein (IAP/CD47) regulates protein levels of SNAP25, $\mathrm{Ca}^{2+}$ kinetics, and synaptic transmission (Numakawa et al., 2004). Our data support the hypothesis that the presynaptic effects of Reelin might be mediated via the integrin pathway as $\beta 1$-integrin was found at presynaptic sites. The rescue effect of Reelin on SNAP25 expression could be neutralized by RGD inhibitor peptides, and wild-type hippocampal slice cultures showed a reeler-like presynaptic vesicle phenotype after RGD peptide treatment.

In conclusion, we provide evidence for an involvement of Reelin in presynaptic functions by regulating neurotransmitter release at hippocampal synapses. The underlying mechanisms do not seem to involve Reelin signaling via lipoprotein receptors and Dab1 but alternative pathways, likely Reelin binding to integrins.

\section{References}

Arnaud L, Ballif BA, Förster E, Cooper JA (2003) Fyn tyrosine kinase is a critical regulator of disabled-1 during brain development. Curr Biol 8:9-17.

Beffert U, Weeber EJ, Durudas A, Qiu S, Masiulis I, Sweatt JD, Li WP, Adelmann G, Frotscher M, Hammer RE, Herz J (2005) Modulation of synaptic plasticity and memory by Reelin involves differential splicing of the lipoprotein receptor Apoer2. Neuron 47:567-579.

Bock HH, Herz J (2003) Reelin activates SRC family tyrosine kinase in neurons. Curr Biol 13:18-26.

Borrell V, Del Río JA, Alcántara S, Derer M, Martínez A, D’Arcangelo G, Nakajima K, Mikoshiba K, Derer P, Curran T, Soriano E (1999) Reelin regulates the development and synaptogenesis of the layer-specific entorhino-hippocampal connections. J Neurosci 19:1345-1358.

Botella-López A, Burgaya F, Gavín R, García-Ayllón MS, Gómez-Tortosa E, Peña-Casanova J, Ureña JM, Del Río JA, Blesa R, Soriano E, Sáez-Valero J (2006) Reelin expression and glycosylation patterns are altered in Alzheimer's disease. Proc Natl Acad Sci U S A 103:5573-5578.

Cai F, Chen B, Zhou W, Zis O, Liu S, Holt RA, Honer WG, Song W (2008) SP1 regulates a human SNAP-25 gene expression. J Neurochem 105:512-523.

Chai X, Förster E, Zhao S, Bock HH, Frotscher M (2009) Reelin stabilizes the actin cytoskeleton of neuronal processes by inducing $\mathrm{n}$-cofilin phosphorylation at serine3. J Neurosci 29:288-299.

Chan CS, Weeber EJ, Kurup S, Sweatt JD, Davis RL (2003) Integrin requirement for hippocampal synaptic plasticity and spatial memory. J Neurosci 23:7107-7116.

Chen Y, Beffert U, Ertunc M, Tang TS, Kavalali ET, Bezprozvanny I, Herz J (2005) Reelin modulates NMDA receptor activity in cortical neurons. J Neurosci 25:8209-8216.

Chen Y, Kundakovic M, Agis-Balboa RC, Pinna G, Grayson DR (2007) Induction of the reelin promoter by retinoic acid is mediated by Sp1. J Neurochem 103:650-665.

Cooper JA (2008) A mechanism for inside-out lamination in the neocortex. Trends Neurosci 31:113-119.

Curran T, D'Arcangelo G (1998) Role of reelin in the control of brain development. Brain Res Brain Res Rev 26:285-294.

D’Arcangelo G, Miao GG, Chen SC, Soares HD, Morgan JI, Curran T (1995) A protein related to extracellular matrix proteins deleted in the mouse mutant reeler. Nature 374:719-723.

D’Arcangelo G, Nakajima K, Miyata T, Ogawa M, Mikoshiba K, Curran T (1997) Reelin is a secreted glycoprotein recognized by the CR-50 monoclonal antibody. J Neurosci 17:23-31.

Deller T, Merten T, Roth SU, Mundel P, Frotscher M (2000) Actinassociated protein synaptopodin in the rat hippocampal formation: localization in the spine neck and close association with the spine apparatus of principal neurons. J Comp Neurol 418:164-181.

Del Río JA, Heimrich B, Borrell V, Förster E, Drakew A, Alcántara S, Nakajima K, Miyata T, Ogawa M, Mikoshiba K, Derer P, Frotscher M, Soriano E (1997) A role for Cajal-Retzius cells and reelin in the development of hippocampal connections. Nature 385:70-74.

Drakew A, Frotscher M, Deller T, Ogawa M, Heimrich B (1998) Developmental distribution of a reeler gene-related antigen in the rat hippocam- pal formation visualized by CR-50 immunocytochemistry. Neuroscience 82:1079-1086.

Dulabon L, Olson EC, Taglienti MG, Eisenhuth S, McGrath B, Walsh CA, Kreidberg JA, Anton ES (2000) Reelin binds alpha3betal integrin and inhibits neuronal migration. Neuron 27:33-44.

Eastwood SL, Harrison PJ (2003) Interstitial white matter neurons express less reelin and are abnormally distributed in schizophrenia: towards an integration of molecular and morphologic aspects of the neurodevelopmental hypothesis. Mol Psychiatry 8:769, 821-831.

Fatemi SH, Earle JA, McMenomy T (2000) Reduction in Reelin immunoreactivity in hippocampus of subjects with schizophrenia, bipolar disorder and major depression. Mol Psychiatry 5:654-663, 571.

Förster E, Tielsch A, Saum B, Weiss KH, Johanssen C, Graus-Porta D, Müller U, Frotscher M (2002) Reelin, Disabled 1, and $\beta 1$ integrins are required for the formation of the radial glial scaffold in the hippocampus. Proc Natl Acad Sci U S A 99:13178-13183.

Förster E, Jossin Y, Zhao S, Chai X, Frotscher M, Goffinet AM (2006a) Recent progress in understanding the role of Reelin in radial neuronal migration, with specific emphasis on the dentate gyrus. Eur J Neurosci 23:901-909.

Förster E, Zhao S, Frotscher M (2006b) Laminating the hippocampus. Nat Rev Neurosci 7:259-267.

Förster E, Bock HH, Herz J, Chai X, Frotscher M, Zhao S (2010) Emerging topics in Reelin function. Eur J Neurosci 31:1511-1518.

Frotscher M (1998) Cajal-Retzius cells, Reelin, and the formation of layers. Curr Opin Neurobiol 8:570-575.

Grayson DR, Jia X, Chen Y, Sharma RP, Mitchell CP, Guidotti A, Costa E (2005) Reelin promoter hypermethylation in schizophrenia. Proc Nat Acad Sci U S A 102:9341-9346.

Haas CA, Dudeck O, Kirsch M, Huszka C, Kann G, Pollak S, Zentner J, Frotscher M (2002) Role for reelin in the development of granule cell dispersion in temporal lobe epilepsy. J Neurosci 22:5797-5802.

Hack I, Hellwig S, Junghans D, Brunne B, Bock HH, Zhao S, Frotscher M (2007) Divergent roles of ApoER2 and Vldlr in the migration of cortical neurons. Development 134:3883-3891.

Hagiwara A, Fukazawa Y, Deguchi-Tawarada M, Ohtsuka T, Shigemoto R (2005) Differential distribution of release-related proteins in the hippocampal CA3 area as revealed by freeze-fracture replica labeling. J Comp Neurol 489:195-216.

Hanson PI, Heuser JE, Jahn R (1997) Neurotransmitter release-four years of SNARE complexes. Curr Opin Neurobiol 7:310-315.

Heinrich C, Nitta N, Flubacher A, Müller M, Fahrner A, Kirsch M, Freiman T, Suzuki F, Depaulis A, Frotscher M, Haas CA (2006) Reelin deficiency and displacement of mature neurons, but not neurogenesis, underlie the formation of granule cell dispersion in the epileptic hippocampus. J Neurosci 26:4701-4713.

Hiesberger T, Trommsdorff M, Howell BW, Goffinet A, Mumby MC, Cooper JA, Herz J (1999) Direct binding of Reelin to VLDL receptor and ApoE receptor 2 induces tyrosine phosphorylation of disabled- 1 and modulates tau phosphorylation. Neuron 24:481-489.

Hilfiker S, Pieribone VA, Czernik AJ, Kao HT, Augustine GJ, Greengard P (1999) Synapsins as regulators of neurotransmitter release. Philos Trans R Soc Lond B Biol Sci 354:269-279.

Howell BW, Hawkes R, Soriano P, Cooper JA (1997) Neuronal position in the developing brain is regulated by mouse disabled-1. Nature 389:733-737.

Impagnatiello F, Guidotti AR, Pesold C, Dwivedi Y, Caruncho H, Pisu MG, Uzunov DP, Smalheiser NR, Davis JM, Pandey GN, Pappas GD, Tueting P, Sharma RP, Costa E (1998) A decrease of reelin expression as a putative vulnerability factor in schizophrenia. Proc Natl Acad Sci U S A 95:15718-15723.

Kulik A, Vida I, Fukazawa Y, Guetg N, Kasugai Y, Marker CL, Rigato F, Bettler B, Wickman K, Frotscher M, Shigemoto R (2006) Compartmentdependent colocalization of Kir3.2-containing $\mathrm{K}^{+}$channels and $\mathrm{GABA}_{\mathrm{B}}$ receptors in hippocampal pyramidal cells. J Neurosci 26:4289-4297.

Lambert de Rouvroit C, Goffinet AM (1998) The reeler mouse as a model of brain development. Adv Anat Embryol Cell Biol 150:1-106.

Maycox PR, Link E, Reetz A, Morris SA, Jahn R (1992) Clathrin-coated vesicles in nervous tissue are involved primarily in synaptic vesicle recycling. J Cell Biol 118:1379-1388.

Niu S, Renfro A, Quattrocchi CC, Sheldon M, D’Arcangelo G (2004) Reelin 
promotes hippocampal dendrite development through the VLDLR/ ApoER2-Dab1 pathway. Neuron 41:71-84.

Niu S, Yabut O, D’Arcangelo G (2008) The Reelin signaling pathway promotes dendritic spine development in hippocampal neurons. J Neurosci 28:10339-10348.

Numakawa T, Ishimoto T, Suzuki S, Numakawa Y, Adachi N, Matsumoto T, Yokomaku D, Koshimizu H, Fujimori KE, Hashimoto R, Taguchi T, Kunugi H (2004) Neuronal roles of the integrin-associated protein (IAP/CD47) in developing cortical neurons. J Biol Chem 279: $43245-43253$.

Ogawa M, Miyata T, Nakajima K, Yagyu K, Seike M, Ikenaka K, Yamamoto H, Mikoshiba K (1995) The reeler gene-associated antigen on CajalRetzius neurons is a crucial molecule for laminar organization of cortical neurons. Neuron 14:899-912.

Parpura V, Mohideen U (2008) Molecular form follows function: (un)snaring the SNAREs. Trends Neurosci 31:435-443.

Pesold C, Impagnatiello F, Pisu MG, Uzunov DP, Costa E, Guidotti A, Caruncho HJ (1998) Reelin is preferentially expressed in neurons synthesizing $\gamma$-aminobutyric acid in cortex and hippocampus of adult rats. Proc Natl Acad Sci U S A 95:3221-3226.

Qiu S, Korwek KM, Pratt-Davis AR, Peters M, Bergman MY, Weeber EJ (2006) Cognitive disruption and altered hippocampus synaptic function in Reelin haploinsufficient mice. Neurobiol Learn Mem 85:228-242.

Rakic P, Caviness VS Jr (1995) Cortical development: view from neurological mutants two decades later. Neuron 14:1101-1104.

Ramos-Moreno T, Galazo MJ, Porrero C, Martínez-Cerdeño V, Clascá F (2006) Extracellular matrix molecules and synaptic plasticity: immunomapping of intracellular and secreted Reelin in the adult rat brain. Eur J Neurosci 23:401-422.

Rice DS, Curran T (2001) Role of the reelin signaling pathway in central nervous system development. Annu Rev Neurosci 24:1005-1039.

Rozov A, Burnashev N, Sakmann B, Neher E (2001) Transmitter release modulation by intracellular $\mathrm{Ca}^{2+}$ buffers in facilitating and depressing nerve terminals of pyramidal cells in layer $2 / 3$ of the rat neocortex indicates a target cell-specific difference in presynaptic calcium dynamics. J Physiol 531:807-826.

Schmid RS, Jo R, Shelton S, Kreidberg JA, Anton ES (2005) Reelin, integrin and DAB1 interactions during embryonic cerebral cortical development. Cereb Cortex 15:1632-1636.

Sheldon M, Rice DS, D’Arcangelo G, Yoneshima H, Nakajima K, Mikoshiba K, Howell BW, Cooper JA, Goldowitz D, Curran T (1997) Scrambler and yotari disrupt the disabled gene and produce a reeler-like phenotype in mice. Nature 389:730-733.

Shono T, Mochizuki Y, Kanetake H, Kanda S (2001) Inhibition of FGF-2mediated chemotaxis of murine brain capillary endothelial cells by cyclic RGDfV peptide through blocking the redistribution of c-Src into focal adhesions. Exp Cell Res 268:169-178.

Soriano E, Del Río JA (2005) The cells of Cajal-Retzius: still a mystery one century after. Neuron 46:389-394.

Stoppini L, Buchs PA, Muller D (1991) A simple method for organotypic cultures of nervous tissue. J Neurosci Methods 37:173-182.

Südhof TC (2004) The synaptic vesicle cycle. Annu Rev Neurosci 27: 509-547.

Tissir F, Goffinet AM (2003) Reelin and brain development. Nat Rev Neurosci 4:496-505.

Trommsdorff M, Gotthardt M, Hiesberger T, Shelton J, Stockinger W, Nimpf J, Hammer RE, Richardson JA, Herz J (1999) Reeler/Disabled-like disruption of neuronal migration in knockout mice lacking the VLDL receptor and ApoE receptor 2. Cell 97:689-701.

Valtorta F, Pennuto M, Bonanomi D, Benfenati F (2004) Synaptophysin: leading actor or walk-on role in synaptic vesicle exocytosis? Bioessays 26:445-453.

Ware ML, Fox JW, González JL, Davis NM, Lambert de Rouvroit C, Russo CJ, Chua SC Jr, Goffinet AM, Walsh CA (1997) Aberrant splicing of a mouse disabled homolog, mdabl, in the scrambler mouse. Neuron 19:239-249.

Wu LG, Saggau P (1994) Presynaptic calcium is increased during normal synaptic transmission and paired-pulse facilitation, but not in long-term potentiation in area CA1 of hippocampus. J Neurosci 14:645-654.

Zhao S, Frotscher M (2010) Go or stop? Divergent roles of Reelin in radial neuronal migration. Neuroscientist 16:421-434.

Zilly FE, Sørensen JB, Jahn R, Lang T (2006) Munc18-bound syntaxin readily forms SNARE complexes with synaptobrevin in native plasma membranes. PLoS Biol 4:e330. 